\title{
The Advantage of Enzyme-linked Immunosorbent Assay (ELISA) as a Method of Microbiological Monitoring for Rat Virus (RV)
}

\author{
Yukiko IZUMI, Tominaga FUKAZAWA, Yoshihiro SUGIYAMA, Ken-ichi YAGAMI, \\ Toru URANO*, and Tsutomu TANIKAWA** \\ Laboratory Animal Research Center, University of Tsukuba, Tsukuba-shi, Ibaraki 305, \\ *Laboratory Animal Research Center, Kumamoto University Medical School, \\ Honjo, Kumamoto-shi, Kumamoto 860, and ${ }^{* *}$ Technical Research \\ Laboratory, Ikari Co. Ltd., Chibadera, Chiba-shi, Chiba 280, Japan
}

(Received 12 December 1990/Accepted 12 April 1991)

\begin{abstract}
An enzyme-linked immunosorbent assay (ELISA) was tested to detect antibodies against rat virus (RV). The purified ELISA antigens were prepared from rat embryonic cells infected with RV-13 (prototype strain) and UT-2 (Japanese isolate), respectively. Western blotting analysis confirmed that both of these antigens had three structural polypeptides $(81 \mathrm{~K}, 61 \mathrm{~K}$, and $59 \mathrm{~K})$. Eleven laboratory and wild rat colonies in Japan were tested for rat virus contamination, serologically. No significant differences in the sero-positive ratio and the distributions of ELISA titers were demonstrated in the ELISA, using antigens from RV-13 and UT-2. ELISA was more sensitive and specific for detecting antibodies against RV from rat serum rather than hemagglutination inhibition (HI) test. This study also confirmed that the RV contaminated widely in colonies of laboratory and wild rats in Japan, and suggested that RV would have to be checked during the microbiological monitoring of laboratory rats. - KEY WORDS : ELISA, microbiological monitoring, parvovirus, rat virus
\end{abstract}

The rat virus (RV), first isolated by Kilham et al. [11] is a member of family Parvoviridae. It causes inapparent infection in adult rats and occasionally causes hepatitis, cerebellar hypoplasia, or hemorrhagic encephalopathy in newborn and sukling rats $[1,8]$. Since RV also contaminates transplantable tumors [2] and results in a symptomatic infection under immunosuppressive condiction [6], it unfavorably affects biomedical research using laboratory rats. Therefore, RV has been the subject of microbiological monitoring for spcific pathogen free (SPF) rats in a few countries, but not yet in Japan. Recently, we have reported the first isolation of $\mathrm{RV}$ in Japan. We have also reported that the newly isolated $R V$ had slight differences in the hemagglutination pattern and antigenicity to the prototype strain of RV [7]. In this study, we attempted an enzyme linked immunosorbent assay (ELISA) to detect the RV antibody in rat serum. The present report also deals with difference between ELISA and the hemagglutination inhibition (HI) test used to detect the RV antibody.

\section{Materials and Methods}

Viruses and cell culture : RV-13 and UT-2 strains of $R V$ were used in this study. The $\mathrm{RV}-13$ strain was supplied by the American Type Culture Collection (ATCC, U. S. A.). The UT-2 strain was previously isolated from an asymptomatic laboratory rat [7]. These viruses were propagated in rat embryo (RE) cell cultures. The RE cells were prepared from a pregnant Slc : Wistar rat, and grown in Eagle's minimum essential medium (MEM) supplemented with a $10 \%$ tryptose phopsphate broth (TPB), a $5 \%$ fetal calf serum(FCS), and antibiotics.

Preparation of the antigen : RE cells were inoculated approximately $1 \mathrm{hr}$ after seeding with the RV at a multiplicity of infection of 
$5 \mathrm{TCID}_{50} /$ cell. When the cytopathic effect was observed in half of infected cells, the medium was pooled and centrifuged at 3,000 rpm for 10 min. The supernatant was stored at $-70^{\circ} \mathrm{C}$ for use as an antigen for hemagglutination inhibition (HI) test, after inactivation by ultraviolet irradiation.

The preparation of the ELISA antigen was carried out according to Tattersall et al. [17, 18] with slight modifications. Briefly, infected cells were suspended with hypotonic buffered solution ( $10 \mathrm{mM} \mathrm{NaCl}, 1.5 \mathrm{mM} \mathrm{MgCl} 2,10 \mathrm{mM}$ Tris- $\mathrm{HCl} \mathrm{pH} 7.4$ ), treated with $0.2 \%$ Nonidet p-40 at $4{ }^{\circ} \mathrm{C}$ for $15 \mathrm{~min}$, and briefly sonicated. After centrifugation at $12,000 \mathrm{rpm}$ for $30 \mathrm{~min}$, the supernatant was precipitated with $25 \mathrm{mM}$ $\mathrm{CaCl}_{2}$ at $4{ }^{\circ} \mathrm{C}$ for $30 \mathrm{~min}$. The precipitate was resuspended in PBS (-) and applied onto double cushions of $40 \% \mathrm{CsCl}$ and $1 \mathrm{M}$ sucrose for ultracentrifugation at $35,000 \mathrm{rpm}$ for $20 \mathrm{hr}$ in a Beckman SW 50.1 rotor. The fractions were collected and frozen at $-70^{\circ} \mathrm{C}$ as the ELISA antigen. The prepared antigen was inactivated with $0.2 \% \quad \beta$-propiolactone at $4{ }^{\circ} \mathrm{C}$ for $2 \mathrm{hr}$ before use.

Sera : A total of 179 serum samples of laboratory and wild rats were collected between 1986 and 1989 . Laboratory rat samples were obtained from nine laboratory animal fecilities and commercial breeders in Japan. Wild rat samples were taken from Rattus rattus and Rattus norvegicus caught in Tokyo.

ELISA procedure: The ELISA was performed as described by Singh and Lang [15]. Briefly, $100 \mu \mathrm{l}$ of the diluted antigen in the coating buffer $\left(14.7 \mathrm{mM} \mathrm{Na}{ }_{2} \mathrm{CO}_{3}, 44.1 \mathrm{mM}\right.$ $\mathrm{NaHCO}_{3}$ ) were dispensed in U-bottomed 96well microplate (Nunc-Immuno Plate, Nunc) wells at $4^{\circ} \mathrm{C}$ overnight. Then the plates were washed once with a washing buffer (PBS containing $0.05 \%$ Tween 20 ). Fifty $\mu$ l of the 2-fold dilutions of sera made with the diluting buffer (PBS containing 1\% Tween 80) were added to each well of the plates. After incubation at $37^{\circ} \mathrm{C}$ for $60 \mathrm{~min}$, the plates were washed 3 times with the washing buffer. The optimum concentration of peroxidase conjugate (rabbit anti-rat immunoglobulins, Dako) was prepared with the diluting buffer and $50 \mu \mathrm{l}$ of the conjugate were added to each well. After incubation at $37^{\circ} \mathrm{C}$ for $60 \mathrm{~min}$, the plates were washed 3 times with the washing buffer. The substrate (citric acid buffer containing $0.04 \%$ o-phenylenediamine and $0.012 \% \quad \mathrm{H}_{2} \mathrm{O}_{2}$ ) was then added to each well. After incubation at $37^{\circ} \mathrm{C}$ for $30 \mathrm{~min}$, the substrate reaction was stopped with $2.5 \mathrm{M} \mathrm{H}_{2} \mathrm{SO}_{4}, 100 \mu \mathrm{l} /$ well. The absorbance at $492 \mathrm{~nm}$ was read with an ELISA plate reader (MODEL 2550 EIA READER, BIORAD).

HI test : A hemagglutination inhibition (HI) test was performed as described previously [7]. The serum was inactivated at $60^{\circ} \mathrm{C}$ for $30 \mathrm{~min}$ and absorbed with kaolin and guinea pig erythrocytes.

Two-fold dilutions of a serum made with PBS containing $0.1 \%$ bovine serum albumin and an antigen preparation containing $8 \mathrm{HA}$ units were mixed in the microplates, and incubated at room temperature for $45 \mathrm{~min}$. After adding the guinea pig erythrocytes and subsequent incubation at room temperature for 2 $\mathrm{hr}$, the HI titer was determined as the reciprocal of the highest serum dilution that inhibited the hemagglutination completely.

Neutralization test : A neutralization $(\mathrm{N})$ test was performed as described previously [7]. Briefly, the serum was inactivated at $60^{\circ} \mathrm{C}$ for $20 \mathrm{~min}$, and 2-fold serum dilutions were made with MEM in the microplates. Then approximately $10^{2} \mathrm{TCID}_{50} / 50 \mu$ l of the virus preparation was added and incubated at $37^{\circ} \mathrm{C}$ for $1 \mathrm{hr}$. After adding RE cells, the plates were incubated at $37^{\circ} \mathrm{C}$ for 6 days. The $\mathrm{N}$-titer was determined as the reciprocal of the highest serum dilution that inhibited completely the hemadsorption of guinea pig erythrocytes.

Western blotting analysis: The purified viruses were separated by sodium dodecyl sulfate polyacrylamide gel electrophoresis (SDSPAGE) according to Mitra et al. [13]. The separated polypeptides were transferred electrophoretically to a nitrocellulose membrane by the method of Cotmore et al. [4] with slight modifications. The blotting membrane was washed with a PBS containing $0.5 \%$ Tween 20 and cut into strips. Each strip was incubated with guinea pig sera immunized with $R V-13$ or UT-2 strain at room temperature for $30 \mathrm{~min}$. After 3 washings, the strips were incubated with peroxidase conjugate at room temperature for $30 \mathrm{~min}$. The immunoreacted protein on the strips was visualized with the substrate (0.05 M Tris- $\mathrm{HCl}$ containing $0.05 \%$ 3, 3'diaminobenzidine tetrahydrochloride and 0.01 $\% \mathrm{H}_{2} \mathrm{O}_{2}$ ) at room temperature. 


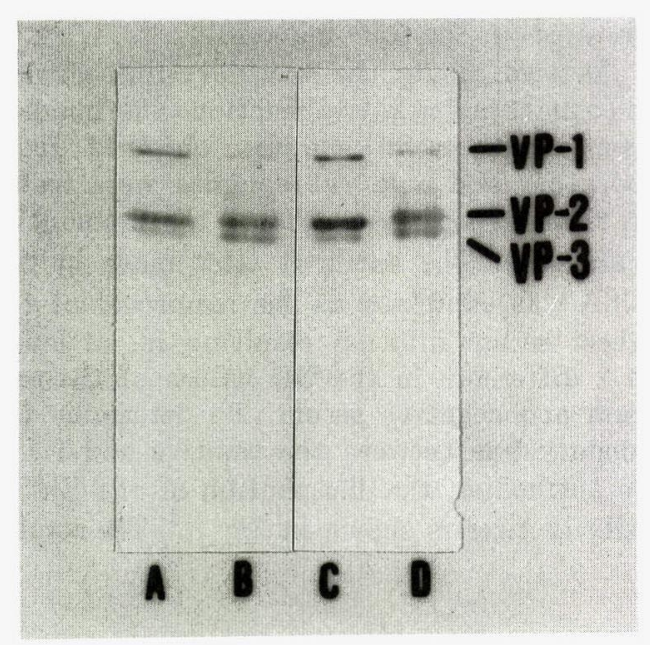

Fig. 1. Western blotting analysis of ELISA antigens prepared from UT- 2 and $\mathrm{RV}-13$ strains A) RV-13 antigen to anti-UT-2 serum B) UT-2 antigen to anti-UT-2 serum C) RV-13 antigen to anti- $R V-13$ serum D) UT-2 antigen to anti-RV-13 serum

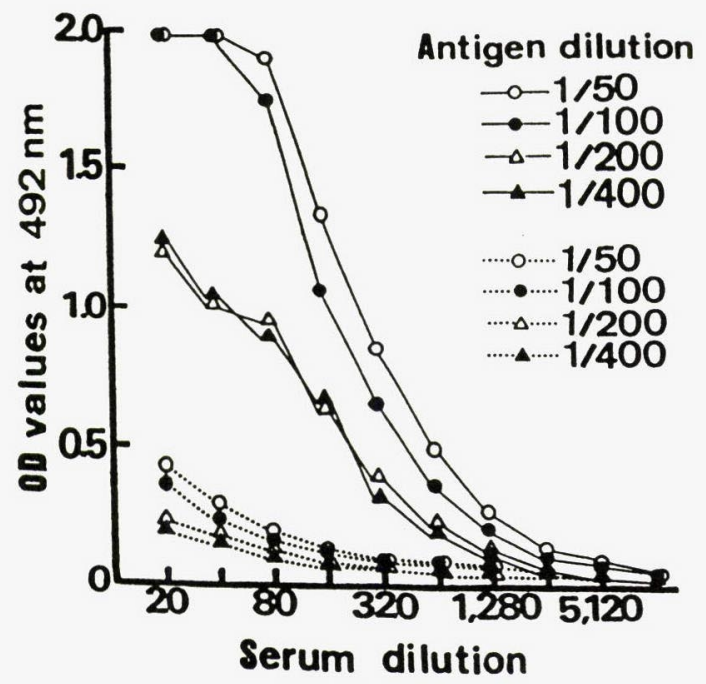

Fig. 2. Optimum concentration of the UT-2 antigen in ELISA. Solid lines ( - ) show reaction curves to positive serum and dotted lines $(\cdot \cdots \cdot)$ ) show reaction curves to negative serum. Serum dilution was expressed as the reciprocal.
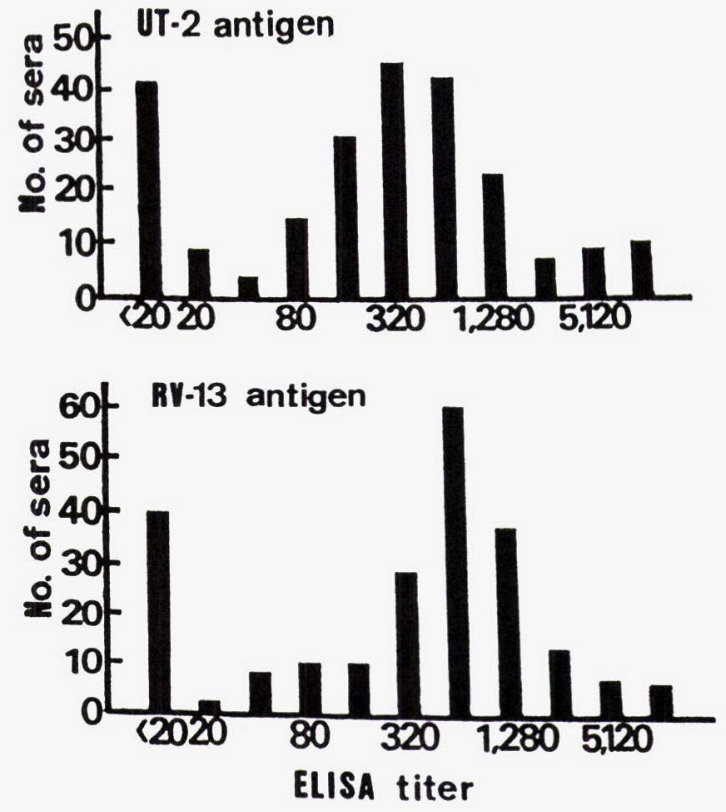

Fig. 3. Distribution of antibody titers against UT-2 and RV-13 antigens, measured by ELISA. A total of 179 sera were tested. ELISA titer is expressed as the reciprocal of the highest serum dilution resulting in, at least, a 0.2 OD value difference from the negative control serum.

\section{Results}

Western blotting analysis of the ELISA antigens : Western blotting analysis was carried out to compare the antigenicity of prototype $\mathrm{RV}-13$ and Japanese isolate UT-2 strains prepared for ELISA antigens. As shown in Fig. 1 , three structural polypeptides (VP-1 VP-2, and VP-3) with molecular weights of $81 \mathrm{~K}$, $61 \mathrm{~K}$, and $59 \mathrm{~K}$ reacted in a manner similar to the respective immune sera against $R V-13$ and UT-2 strains. This indicated that there was no antigenic difference between the two $R V$ strains.

Determining the optimal antigen and the conjugate concentration: The optimal antigen and conjugate concentrations in the ELISA were first determined by checkerboard titration. Each antigen was diluted from $1: 50$ to $1: 400$ with the coating buffer and reacted with the serially diluted serum. The positive 
serum of naturally infected rat and negative serum obtained from the RV-free (tested by $\mathrm{HI}$ and immunofluorescence procedure) colony were used to show the reactivities (Fig. 2). The results indicated that the $1: 100$ dilution was the minimum concentration for adequate reaction of the positive serum with OD $492 \mathrm{~nm}$. Similarly, peroxidase conjugate was diluted from $1: 1000$ to $1: 3000$ with a diluting buffer and used for the ELISA. One to two thousands dilution was determined as optical conjugate concentration by reactivities with positive and negative serum. Therefore, $1: 100$ dilution of antigens and 1:2000 dilution of conjugate were used for the follwing assay.

Determinating the boundary line between the positive and negative reaction: One hundred seventy-nine serum samples obtained from laboratory and wild rat colonies were tested for the antibody to both the UT-2 and RV13 antigens. The antibody titer made by the ELISA was expressed as the reciprocal of the highest serum dilution resulting in, at least, a 0.2 difference in the OD values of the test serum and negative serum. To determine the boundary line between the positive and negative antibodies, the distribution of the ELISA antibody titer is shown in Fig. 3. The results
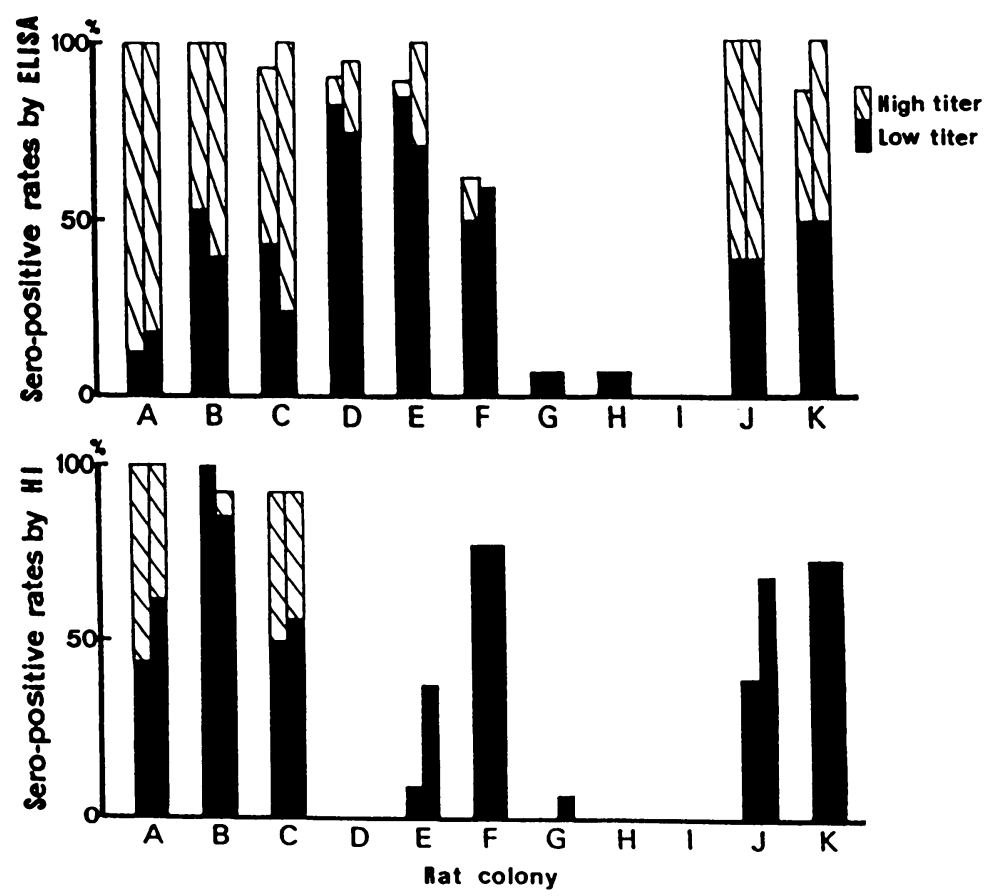

Fig. 4. Sero-positive ratio and distributions of ELISA and HI antibody against UT- 2 and $\mathrm{RV}-13$ antigens in laboratory rat (A, B, $\mathrm{C}, \mathrm{D}, \mathrm{E}, \mathrm{F}, \mathrm{G}, \mathrm{H}$ and $\mathrm{I})$ and wild rat ( $\mathrm{J}$ and $\mathrm{K}$ ) colonies. ELISA titer was expressed as the reciprocal of the highest serum dilution resulting in at least, a $0.2 \mathrm{OD}$ value difference from the negative control serum. HI titer was expressed as the reciprocal of the highest serum dilution completely inhibited $8 \mathrm{HA}$ of the antigen. ELISA titer above 80 and HI titer above 20 were scored as positive. In one colony, left column indicates sero-positive ratio against UT-2 antigen and right column indicates the ratio against RV-13 antigen. In a same column, slantly lined part indicates a rate of higher titer (above 1, 280 in both ELISA and $\mathrm{HI}$ ) serum and a painted part indicates a rate of lower titer (80 to 640 in ELISA, and 20 to 640 in $\mathrm{HI}$ ) serum in the colony. 


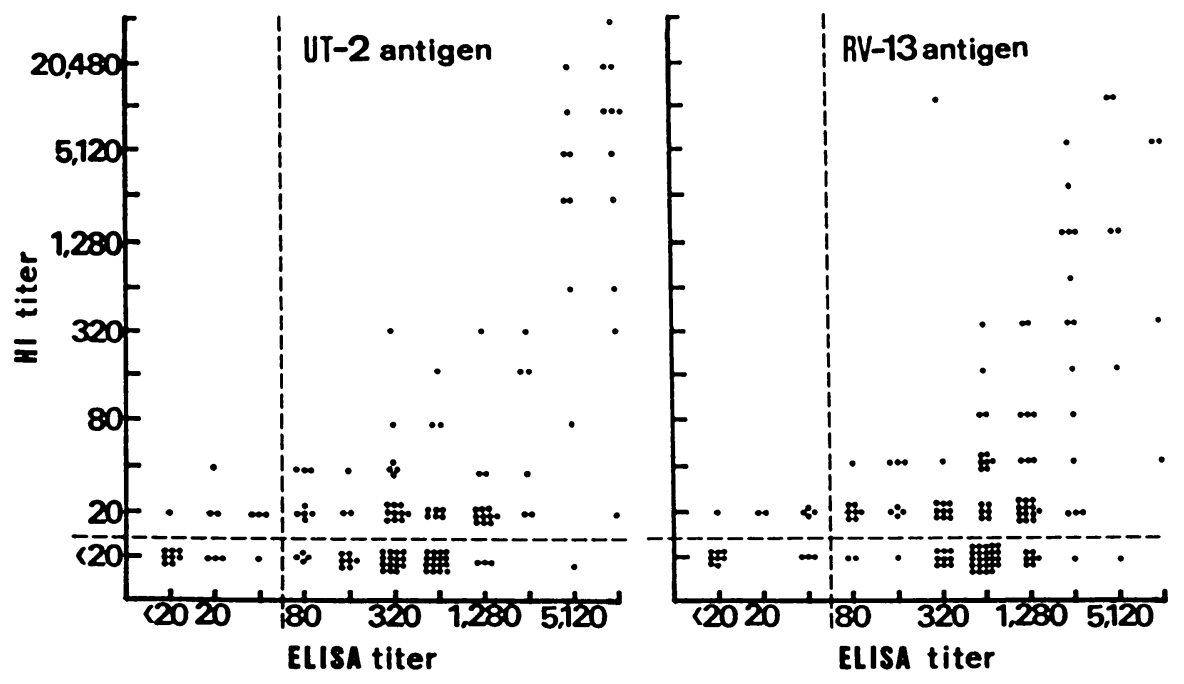

Fig. 5. Correlation between antibody titers of ELISA and HI, against UT-2 $(r=0.57)$ and RV-13 $(r=0.51)$ antigens. Vertical dotted lines distinguish positive and negative in ELISA titers. Horizontal dotted lines distinguish positive and negative in $\mathrm{HI}$ titers.

Table 1. Titers of ELISA, HI, and neutralizing (NT) antibodies against RV in rat sera which are negative in HI but positive in ELISA

\begin{tabular}{|c|c|c|c|c|c|c|c|c|c|}
\hline \multirow{3}{*}{$\begin{array}{l}\text { Serum } \\
\text { specimen }\end{array}$} & \multirow{3}{*}{$\begin{array}{l}\text { No. of tested } \\
\text { sera }\end{array}$} & \multicolumn{8}{|c|}{ Antibody titers } \\
\hline & & \multicolumn{2}{|c|}{$\mathrm{HI}$} & \multicolumn{3}{|c|}{ ELISA } & \multicolumn{3}{|c|}{ NT } \\
\hline & & $<20$ & $20 \leqq$ & $<80$ & $80-640$ & $1,280 \leqq$ & $<2$ & $2-32$ & $64 \leqq$ \\
\hline Examined sera & 46 & 46 & 0 & 0 & 42 & 4 & 0 & 27 & 19 \\
\hline Positive control $^{\mathrm{a})}$ & 4 & 0 & 4 & 0 & 0 & 4 & 0 & 0 & 4 \\
\hline Negative control ${ }^{\text {b) }}$ & 5 & 5 & 0 & 5 & 0 & 0 & 5 & 0 & 0 \\
\hline
\end{tabular}

a) Positive control sera with higher titers in both ELISA and HI test were selected.

b) Negative control sera in both ELISA and HI test were selected.

indicated that serum specimens could be divided into two groups of negative and positives. The border line between the positive and negative specimens seemed to range from 20 to 80 . Therefore, the serum showing an ELISA titer greater than 80 was regarded as antibodypositive against each antigen in this study.

A correlation of the antibody titers between the ELISA and the HI test : The 179 serum samples from 9 laboratory rat colonies, conventional rat colonies $(A, B, C, D, E$ and $F$ ) and specific pathogen free rat colonies $(G, H$ and $\mathrm{I})$, and 2 wild rat colonies ( $\mathrm{J}$ and $\mathrm{K}$ ) were also tested for $\mathrm{HI}$ antibodies against both the UT- 2 and RV-13 antigens. Fig. 4 shows the results of the sero-positive ratio and distribution of titers in 11 colonies. In the $\mathrm{D}$ and $\mathrm{E}$ colonies, significant differences in the seropositive ratio by the ELISA and HI were seen. The sero-positive ratio obtained by the ELISA were usually higher than those by the $\mathrm{HI}$, and reached to nearly $100 \%$ in most of sero-positive colonies. In ELISA, no significant differences between the UT-2 and RV-13 antigens were observed in the sero-positive ratio of each colony. 
The antibodies titers detected by ELISA and $\mathrm{HI}$ test, were shown to correlate at $\mathrm{r}=0.57$ against the UT- 2 antigen, and at $r=0.51$ against the RV-13 antigen (Fig 5). Most of the serum showed higher titer in ELISA than in HI. In $58 \mathrm{HI}$ negative (titer of $<20$ ) sera against UT-2, 46 specimens were considered to be positive in ELISA. Similarly, among $56 \mathrm{HI}$ negative sera, 45 were positive in ELISA against RV-13. To assure the specificity of the ELISA in these sera, neutralizing antibodies were also tested. Surely, these samples had neutralizing antibodies against RV (Table 1). Thus, it was confirmed that ELISA could detect a very small amount of the antibody which was not detected by HI test.

\section{Discussion}

Microbiological monitoring of specific pathogenic organisms was performed as one of the methods for assessing the health of laboratory animals or controlling quality in the breeding colonies of laboratory animals. The selection of organisms and the procedure should be revised according to existing epidemic conditions and the needs of researchers. The present study is to develop the ELISA for microbiological monitoring of the $\mathrm{RV}$ infection which has not yet been monitored in Japan.

The specific reaction is required in standarized procedure for microbiological monitoring. Among rodent parvoviruses, such as the minute virus of mice (MVM), $\mathrm{H}-1, \quad \mathrm{HER}$ and $R V$, a serologic crossreactivity has been shown by the immunofluorescent antibody (IFA) test, but not by the HI, neutralization and complement fixation tests $[5,12]$. The cross-reactivity of rodent parvoviruses could be due to virus-coded, non-structural protein which was recognized for several autonomous parvoviruses $[3,14]$. In the present study, the crossreactivity to other rodent parvoviruses would be eliminated in ELISA, since ELISA antigen was prepared from purified viral particles which did not contain non-structural protein.

Besides, we have previously reported that there were slight differences in the HA pattern and antigenicity of the prototype RV-13 strain and the UT-2 strain newly isolated in Japan [7]. In the present study, however, no significant differences in the ELISA titers and seropositive ratio of the respective colonies was observed using two different antigens. The antigenic differences between RV-13 and UT--2 strains might be virtually eliminated in the ELISA using field serum samples, but not in the hyperimmune serum samples. Thus, the results indicated that either the $\mathrm{RV}-13$ or UT-2 strains were similarly useful to prepare the ELISA antigens.

The results shown here indicate that the sensitivity of the ELISA is higher than that of the $\mathrm{HI}$, and that the sero-positive or negative determination by the ELISA is well correlated with the results of the HI except in the sera from $\mathrm{D}$ and $\mathrm{E}$ colonies. There was a significant difference between the positive ratio by the ELISA and the HI in these colonies. However, these serum samples, which were sero-negative by the $\mathrm{HI}$ and yet sero-positive by the ELISA, should have specific neutralizing antibody against RV. Since there were variations on the HA pattern of $R V$ in isolated strains $[7,19]$, variant strains, in which the HA pattern was different from that of the RV-13 and UT-2 strains, might contaminate the $\mathrm{D}$ and $\mathrm{E}$ colonies.

Recently, the ELISA has been used as a sensitive and specific sero-diagnostic method for detecting several microbiological organisms in laboratory animals $[9,10,16]$. Our results also indicate that the ELISA is a highly sensitive and specific methods for sero-monitoring the RV infection, comparable to the HI test corrently used widely. In conclusion, we consider the ELISA is more suitable method than the $\mathrm{HI}$ test for testing antibodies against RV. Furthermore, we have shown that the RV infection is widely distributed in laboratory rat colonies. We propose that the microbiological monitoring of $\mathrm{RV}$ should be undertaken for laboratory rats in Japan.

\section{References}

[1] Baringer, J. R. and Nathanson, N. (1972). Parvovirus hemorrhagic encephalopathy of rats. Electron microscopic observations of the vascular lesions. Lab. Invest., 27, 514-522.

[2] Campbell, D. A., Staal, S. P, Manders, E. K., Bonnard, G. D., Oldham, R. K., Salzman, L. A., and Herberman, R. B. (1977). Inhibition of in vitro lymphoproliferative responses by in viwo passaged rat 13762 mammary adenocarcinoma cells. II. Evidence that Kilham rat virus is responsible for the inhibitorye ffect. Cell. Immunol, 33, 378-391.

[3] Cotmore, S. F., Sturzenbecker, L. J. and Tattersall, P. (1983). The autonomous parvovirus MVM enco- 
[11] Kilham, L. and Olivier, L. J. (1959). A latent virus of rats isolated in tissue culture. Virology, 7, 428437.

[12] Mengeling, W. L., Paul, P. S., Bunn, T. O., and Ridpath, J. F. (1986). Antigenic relationships among autonomous parvoviruses. J. gen. Virol, 67, 28392844.

[13] Mitra, S., Snyder, C. E., Bates, R. C., and Banerjee, P. T. (1982). Comparative physicochemical and biological properties of two strains of kilham rat virus, a non-defective parvovirus. J. gen. Virol, 61, 43-54.

[14] Mitra, R., Wali, T., Valdez, V., Fabisch, P., and Salzman, L. A. (1983). Transcription and translation in the autonomous parvovirus KRV. Virology, 125, 349-360.

[15] Singh, S. B. and Lang, C. M. (1984). Enzyme-linked immunosorbent assay in the diagnosis of Kilham rat virus infection in rats. Lab. Anim, 18, 364-370.

[16] Takakura, A., Kagiyama, N., Sakurai, Y., Suzuki, H., Kobayashi, N., and Terada, E. (1988). Detection of Sendai virus antibody in mouse and guinea pig sera by an enzyme-linked immunosorbent assay with protein A. Exp. Anim, 37, 279-283.

[17] Tattersall, P., Cawte, P. J., Shatkin, A. J., and Ward, D. C. (1976). Three structural polypeptides coded for by minute virus of mice, a parvovirus. J. Virol, 20, 273-289.

[18] Tattersall, P. and Bratton, J. (1983). Reciprocal productive and restrictive virus-cell interactions of immunosuppressive and prototype strains of minute virus of mice. J. Virol, 46, 944-955.

[19] Toolan, H. W. (1967). Agglutination of the H-Viruses with various types of red blood cells. Proc. Soc. Exp. Biol Med, 124, 144-146. des two nonstructural proteins in addition to its capsid polypeptides. Virology, 129, 333-343.

[4] Cotmore, S. F., Mckie, V. C., Anderson, L. J., Astell, C. R., and Tattersall, P. (1986). Identification of the major structural and nonstructural proteins encoded by human parvovirus B 19 and mapping of their genes by procaryotic expression of isolated genomic fragments. J. Virol, 60, 548-557.

[5] Cross, S. S. and Parker, J. C. (1972). Some antigenic relationships of the murine parvoviruses: Minute virus of mice, rat virus, and $\mathrm{H}-1$ Virus. Proc. Soc. Exp. Biol Med, 139, 105-108.

[6] ElDadah, A. H., Nathanson, N., Smith, K. O., Squire, R. A., Santos, G. W., and Melby, E. C. (1967). Viral hemorrhagic encephalopathy of rats. Science, 156, 392-394.

[ 7 ] Fukazawa, T., Sugiyama, Y., and Yagami, K. (1990). Characterization of newly isolated rat viruses from asymptomatic laboratory rats. Arch Virol, 115, $115-121$

[8] Jacoby, R. O., Bhatt, P. N., Gaertner, D. J., Smith, A. L., and Johnson, E. A. (1987). The pathogenesis of rat virus infection in infant and juvenile rats after oronasal inoculation. Arch Virol, 95, 251-270.

[9] Kagiyama, N., Takakura, A., Terada, E., Sakurai, Y., and Suzuki, H. (1990). Studies on the development of an ELISA kit for microbiological monitoring. 1 . Evaluation of the reliability of the prototype kit by field tests. Exp. Anim, 39, 89-96.

[10] Kagiyama, N., Takakura, A., Terada, E., Sakurai, Y., and Suzuki, H. (1990). Studies on the development of an ELISA kit for microbiological monitoring. 2 . Improvement of the prototype ELISA kit with special references to mouse hepatitis virus antigen. Exp. Anim, 39, 97-102.

\section{ELISA による抗ラットゥイルス抗体検出法の 微生物モニタリングへの活用}

泉幸子・深澤富長・杉山芳宏・八神健一 浦野徹*・谷川 力**

筑波大学動物実験センター

*能本大学医学部付属動物実験施設

**イカリ消毒株式会社技術研究所

ラットゥイルス (RV) 抗体検出法として, ELISA の 応用を試みた。精製 ELISA 抗原は, RV-13（標準株） 及びUT-2 (国内分離株) をそれぞれ感染させたラッ 卜胎仔細胞から作製した。これら両株とも 3 種 $(81 \mathrm{~K}$, $61 \mathrm{~K}, 59 \mathrm{~K})$ のキャプシド蛋白を同程度に含むことが western blotting 解析により確認された。また国内 の実験用ラット及び野生ラットコロニー, 計11コロニから採取したラット血清に対し，2株の抗原を用いて
ELISA を行なった。各コロニーでの抗体陽性率及び抗 体価分布においても2 抗原間の差はみられなかった。ま た，ELISA は HI 試験より高感度で特異性も高かった。 さらに，国内の多くのラットコロニーが RVによって污 染されていることが改めて確かめられた。今後, SPF ラットの微生物モニタリング項目として， RV を取り上 げることが重要と考えられる。 